\title{
Revision of so-called Pomatoschistus (Gobiiformes, Teleostei) from the late Eocene and early Oligocene
}

\author{
Christoph Gierl and Bettina Reichenbacher
}

\begin{abstract}
The Gobiiformes (Teleostei) are among the most speciose groups of vertebrates, and are found in all aquatic habitats. Identification of extant gobiiform species is primarily based on soft-tissue characters, and their diversity and phenotypic variability often makes species determination difficult. Fossils normally lack soft-tissue features, and secure assignment of fossil Gobiiformes at family and genus levels can be extremely problematical. "Pomatoschistus bleicheri (Sauvage)" from the lower Oligocene of Rouffach (France) and "Pomatoschistus(?) cf. bleicheri (Sauvage)" from the upper Eocene of the Isle of Wight (England) exemplify these difficulties. These finds are of special interest, because they may represent the oldest fossil skeleton-based members of the Gobiidae + Oxudercidae (gobiiforms with five branchiostegals; hereafter 5brG). Reexamination of the type material of those two species now reveals the presence of a premaxilla with a postmaxillary process, which precludes assignment of these fossils to the genus Pomatoschistus. Indeed, they do not even belong to the $5 \mathrm{brG}$ because they display six branchiostegals. We conclude that the fossils from France and England both belong to $†$ Paralates Sauvage. Differences in the shape of the frontal bones and the numbers of caudal fin rays allow us to assign the French material to $+P a$. bleicheri Sauvage and the English specimens to $† P a$. chapelcorneri $\mathrm{n}$. sp. Thus the oldest currently known 5brG species based on articulated skeletons is †Gobius jarosi Prikryl and Reichenbacher, 2017 from the lower Miocene.
\end{abstract}

Christoph Gierl. Department of Earth and Environmental Sciences, Ludwig-Maximilians-Universität München, Richard-Wagner Straße 10, 80333 Munich, Bavaria, Germany; c.gierl@Irz.uni-muenchen.de Bettina Reichenbacher. Department of Earth and Environmental Sciences, Ludwig-Maximilians-Universität München, Richard-Wagner Straße 10, 80333 Munich, Bavaria, Germany; b.reichenbacher@Irz.unimuenchen.de

Keywords: Fossil gobiiform; new species; Gobiidae; Oxudercidae; branchiostegals

Submission: 7 September 2016 Acceptance: 14 June 2017

http://zoobank.org/517F0A5F-A93C-4328-BA23-64F8062D97A8

Gierl, Christoph and Reichenbacher, Bettina. 2017. Revision of so-called Pomatoschistus (Gobiiformes, Teleostei) from the late Eocene and early Oligocene. Palaeontologia Electronica 20.2.33A: 1-17

palaeo-electronica.org/content/2017/1909-revision-of-pomatoschistus 


\section{INTRODUCTION}

Gobiiformes are a group that shows high species diversity in marine, brackish and freshwater habitats (Patzner et al., 2011) with numerous adaptations to varied niches in these environments (e.g., Thacker, 2011). Their systematics at the family level was initially based on characteristic suites of morphological characters and has, more recently, been largely confirmed by studies using molecular data (e.g., Miller, 1973; Hoese and Gill, 1993; Johnson and Brothers, 1993; Thacker, 2009; Thacker and Roje, 2009; Agorreta et al., 2013; Thacker et al., 2015). A simplified phylogeny is given in Figure 1. Note that we use Oxudercidae instead of Gobionellidae because the latter is a junior synonym of the former (Nelson et al., 2016).

The fossil record of the Gobiiformes dates back to the lower Eocene (Gaudant, 1996; Bajpai and Kapur, 2004; Bannikov and Carnevale, 2016). Notably the Eocene skeleton-based fossils have not been assigned to any of the extant families, either owing to incomplete preservation (Gaudant, 1996) or because of an unusual character set (Bannikov and Carnevale, 2016). Also the Eocene "gobiid" otoliths described by Bajpai and Kapur (2004) probably do not belong to the Gobiidae but rather represent basal Gobiiformes such as Odontobutidae and Eleotridae (see Gierl et al., 2013).
The oldest skeleton-based records currently assigned to Gobiidae are those of "Pomatoschistus(?) cf. bleicheri (Sauvage, 1883)" from the upper Eocene of the Isle of Wight in England (Gaudant and Quayle, 1988) and "Pomatoschistus bleicheri (Sauvage, 1883)" from the lower Oligocene of the southern sector of the Upper Rhine Graben in France (Sauvage, 1883; Gaudant, 1979). Both have been provisionally assigned to Pomatoschistus, as these authors stated. Gaudant (1979) and Gaudant and Quayle (1988) observed certain features of the skeletons that were later recognized as important for distinguishing gobiids and oxudercids from all other gobiiform families (Gill and Mooi, 2012) and for discrimination within gobiid and oxudercid groups (e.g., McKay and Miller, 1997). The objective of this work is to re-investigate the previously described fossil material in the light of the newer literature and determine whether or not these specimens actually represent species of Pomatoschistus and thus a member of the Oxudercidae.

\section{MATERIALS AND METHODS}

The re-investigated specimens of "Pomatoschistus bleicheri" comprise seven articulated skeletons and one skull from the quarry at Rouffach (France). This material is kept in the Naturhis-

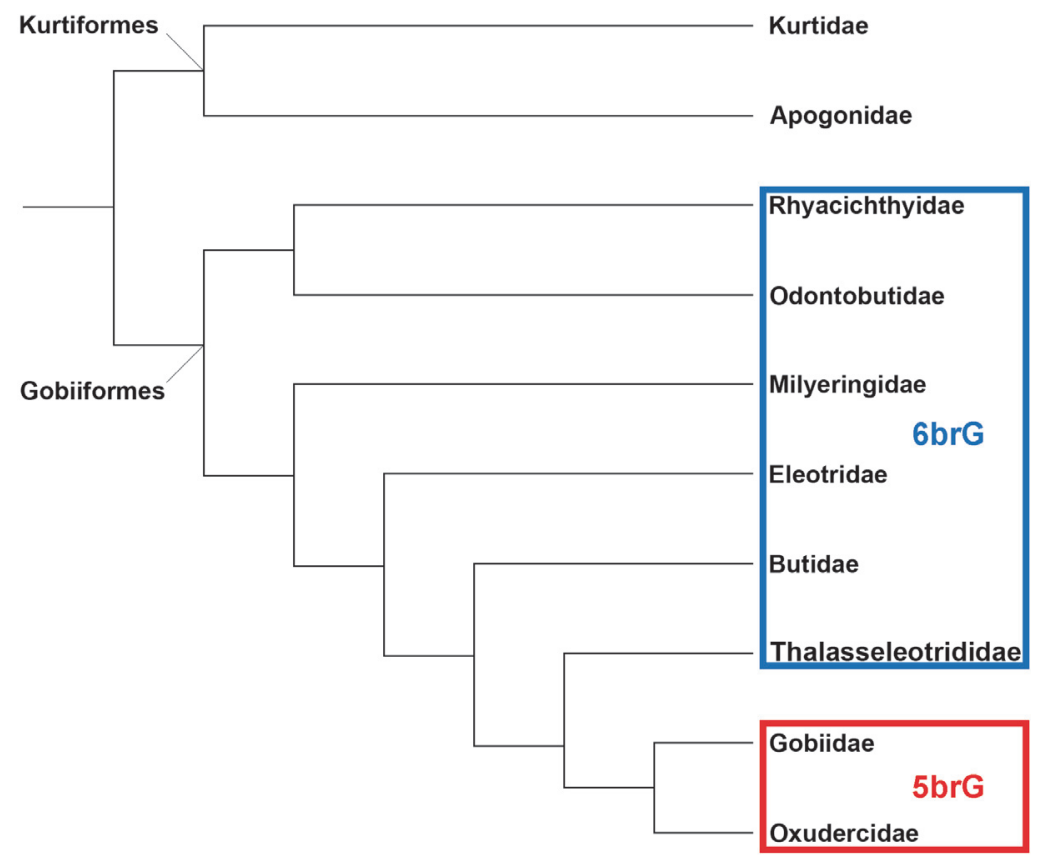

FIGURE 1. Phylogeny of the Gobiiformes according to Thacker et al. (2015) and Nelson et al. (2016). 6brG = gobiiforms with six branchiostegal rays, $5 \mathrm{brG}=$ gobiiforms with five branchiostegal rays. 
torisches Museum Basel (NMB) under the collection numbers NMB Ruf 13_1 (skull), NMB Ruf. 6a/b, NMB Ruf. 9_1, NMB Ruf. 9_2, NMB Ruf. 11, NMB Ruf. 13_2 (counterpart of NMB Ruf. 11), NMB Ruf. 15a/b, NMB Ruf. 18. Additional specimens from Rouffach are curated in the NMB, but their preservation is very poor.

The re-investigated "Pomatoschistus cf. bleicheri" fossils $(n=5)$ from the Isle of Wight include all available well-preserved specimens but one, which is in a private collection (see Gaudant and Quayle, 1988, p. 31). Three of these specimens are deposited in the Natural History Museum, London (NHMUK, previously BMNH) under the numbers NHMUK PV P 59784, NHMUK PV P 59785 (plus 59785_counterpart) and NHMUK PV P 59786, further poorly preserved specimens are NHMUK PV P 59774, NHMUK PV P 59775, NHMUK PV P 59776, NHMUK PV P 59777, NHMUK PV $P$ 59787, NHMUK PV $P$ 59788, NHMUK PV P 59797. The other two well-preserved specimens are kept in the Sedgwick Museum of Earth Sciences, Cambridge (SM) as SM C.23632 and SM C.23633.

Meristic and osteological characters of the skeletons were studied under a stereomicroscope equipped with a digital camera. Counts of rays in the caudal fin follow Fricke (1983). Counts of vertebrae include the uroterminal centrum. Measurements were taken with ImageJ v1.51a 64-bit (Rasband, 1997-2016) based on the digital images. Unless otherwise indicated, pictures were taken by the first author, and the figures were prepared using Adobe Photoshop CS6 (13.0.6) 64-bit. Institutional abbreviations: NHMUK (Natural History Museum, London), NMB (Naturhistorisches Museum Basel), SM (Sedgwick Museum of Earth Sciences, Cambridge).

Other abbreviations: $6 \mathrm{brG}$ for gobiiforms with six branchiostegal rays; $5 \mathrm{brG}$ for gobiiforms with five branchiostegal rays; D2C for the distance between the end of second dorsal fin and the first dorsal (procurrent) ray of the caudal fin.

\section{SYSTEMATIC PALAEONTOLOGY} (2016).

Taxonomic classification follows Nelson et al.

\section{Series PERCOMORPHA sensu Johnson and Patterson, 1993}

Subseries GOBIIDA Nelson et al., 2016

Order GOBIIFORMES Günther, 1880

Family incertae sedis

Genus †Paralates Sauvage, 1883
Emended diagnosis. Six branchiostegals; first dorsal fin with seven spines; number of vertebrae 29 to 31; base of second dorsal fin shorter than D2C.

Type species. †Paralates bleicheri Sauvage, 1883

†Paralates bleicheri Sauvage, 1883

Figures 2, 3.1, 4

* 1883 Paralates bleicheri Sauvage: 483-485, pl. XI, figs. 1-2.

1913 Paralates cf. bleicheri Sauvage. - Förster: 45, pl. III, fig. 37.

1934 Prolebias praecursor Weiler. - Théobald: 122 (pro parte).

1941 Paralates bleicheri Sauvage. - Maïkovsky: 55, pl. XII, fig. 86.

v1979 Pomatoschistus bleicheri (Sauvage). Gaudant: 131-137, pl. I, figs. 1-4.

?1981 Pomatoschistus bleicheri (Sauvage). - Gaudant: 214, pl. I, fig. 4.

Material. A total of 29 specimens from Rouffach are curated in the NMB (NMB Ruf. 1 to NMB Ruf. 29); these specimens represent the entire material of the species available. Only seven articulated skeletons and one skull were well- preserved and served as the basis for this study: NMB Ruf. 13_1 (skull), NMB Ruf. 6a/b, NMB Ruf. 9_1, NMB Ruf. 9_2, NMB Ruf. 11, NMB Ruf. 13_2 (counterpart of 11), NMB Ruf. 15a/b, NMB Ruf. 18 . The type material described by Sauvage (1883) is lost. Therefore Gaudant (1979) designated NMB Ruf. 15b as neotype.

Emended diagnosis. Small gobiiform fish ranging from 29 to about $55 \mathrm{~mm}$ in length. Body cylindrical. Head length about three times included in the standard length. Frontal bones anteriorly less than onethird of the width of the posterior part. First dorsal with seven spines. Total number of vertebrae: $29-$ 30. Four to six (?seven) simple rays (=unbranched, unsegmented) in caudal fin dorsally and ventrally.

Description. For meristic characters and morphometric distances see Tables 1 and 2. The description of the skull is mainly based on NMB Ruf. 13_1.

The orbital region of the frontals (Figures 2.1, 3.1 ) is very narrow, less than one-third as broad as their posterior parts (also in NMB Ruf. 11). Other elements of the skull roof are certainly present, but are unidentifiable within the brownish mass. Of the ethmoid region only parts of the mesethmoid and the vomer are also recognizable.

In the jaws the premaxilla shows a broad postmaxillary process and a smaller articular process. A spine-like ascending process is not preserved (Figure 2.1). The maxilla is slender and bent, with a 

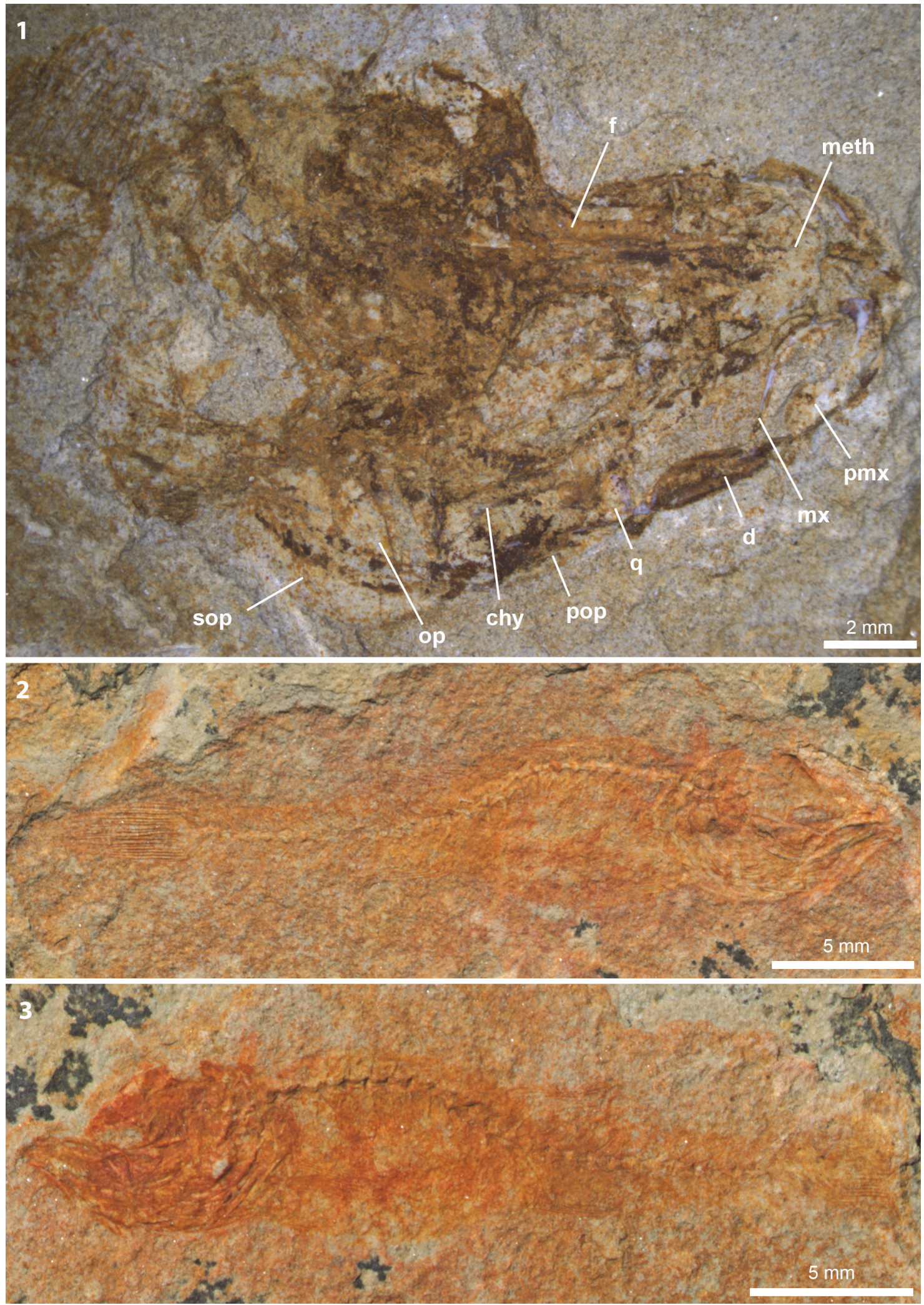

FIGURE 2. †Paralates bleicheri Sauvage, 1883. 1. NMB Ruf. 13 1 1 skull. 2. NMB Ruf. 15b (Neotype, designated by Gaudant, 1979). 3. NMB Ruf. 15a. Abbreviations: chy = ceratohyal, $d=$ dentary, $f=$ frontal, $m x=$ maxilla, meth $=$ mesethmoid, $o p=$ opercle,$p m x=$ premaxilla, $p o p=$ preopercle,$q=$ quadrate, sop $=$ subopercle. (Photos by M. Schellenberger.) 


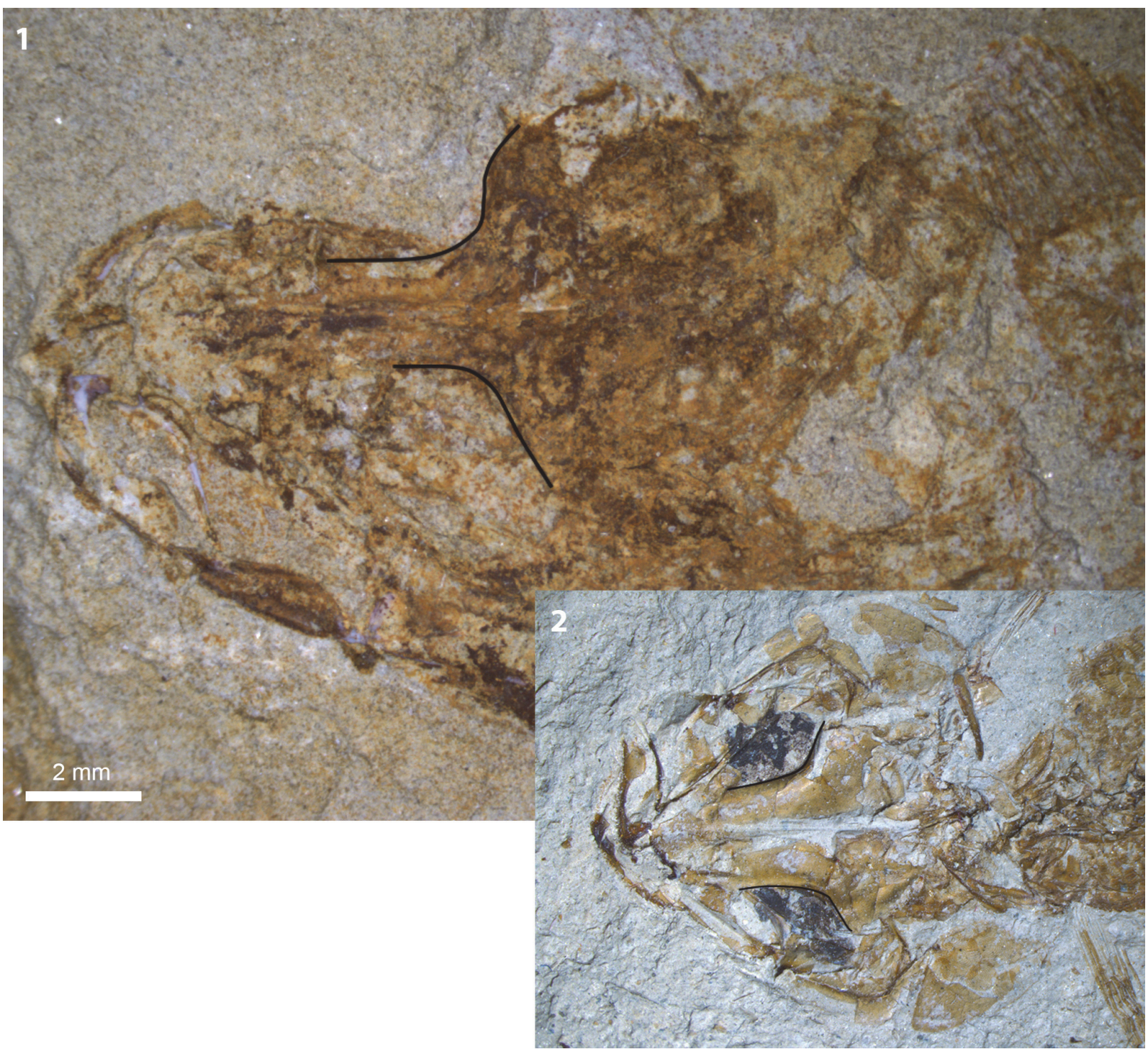

FIGURE 3. Comparison of frontals (highlighted by the black lines). 1. †Paralates bleicheri Sauvage, 1883, NMB Ruf. 13_1 skull mirrored. (Photo by M. Schellenberger.) 2. †Paralates chapelcorneri n. sp., NHMUK PV P 59786. Same scale for both skulls.

thick and forked articular process. The dentary is broad posteriorly and narrows anteriorly. Teeth are not preserved.

Most parts of the suspensorium and the hyoid arch are not identifiable. The quadrate is triangular and has a slender posteroventral process. The ceratohyal is broad in the short posterior part, while its long anterior part is quite slender. The epihyal (=posterior ceratohyal) is not preserved. Branchiostegals are not preserved.

The opercle is triangular and the subopercle is crescent-shaped. The preopercle is partially visible.
The vertebral column consists of 29 to 30 vertebrae, of which 17 or 18 are post-abdominal. The number of rib pairs seems to be at least eight.

The cleithrum is thick and slightly curved. The dorsally placed post-temporal is a rather robust $\mathrm{V}$ shaped bone. The rest of the pectoral girdle is not recognizable.

The pelvic girdle is triangle-shaped in its posterior part and forms with its counterpart a rhombus-like structure. The fins consist of one spine and five rays each.

The first dorsal fin has seven spines, while the second has one spine and 10 rays. The base of the second dorsal is clearly shorter than the caudal 

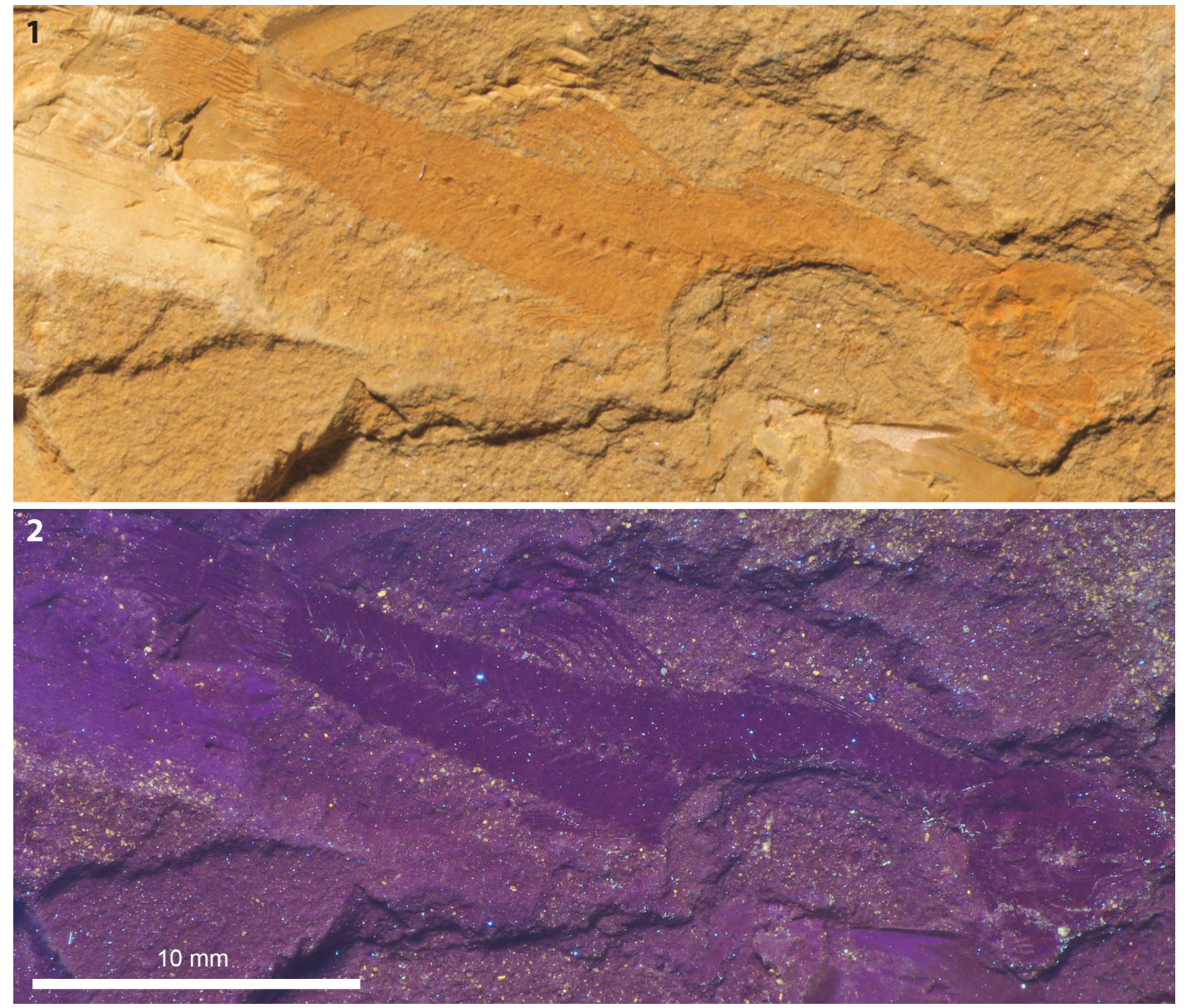

FIGURE 4. †Paralates bleicheri Sauvage, 1883, NMB Ruf. 18. 1. Viewed under normal light. (Photo by M. Schellenberger.) 2. Imaged with UV light. (Photo by $\mathrm{H}$. Tischlinger.)

peduncle. This is also true for the anal fin, which has one spine and eight or nine rays, and lies slightly behind the second dorsal fin.

The caudal endoskeleton consists of two hypural plates (hy1+2, hy $3+4$ ). Hypural $3+4$ is fused to the terminal centrum (urostyle). Hypural 5 is long and slender, as is the parhypural. Epurals are not preserved. The caudal fin has 12 segmented and branched rays, two specimens may have up to 13 segmented and branched rays (see Table 1). One or two segmented and unbranched rays occur dorsally and ventrally, and four to possibly seven simple rays (=unsegmented and unbranched) are inserted dorsally and ventrally.

Scales and otoliths are not preserved.

Remarks. The species †Paralates bleicheri was first described by Sauvage (1883) from the site Rouffach in the Upper Rhine Graben. As the genus name suggests, Sauvage thought this represented a perch-like fossil. Furthermore, he mentioned the presence of seven branchiostegals and two anal fin spines, but these characters are not mentioned in the later descriptions by Gaudant $(1979,1981)$ and are also absent in the specimens examined here. Nevertheless, judging by the rest of the original description (Sauvage, 1883), e.g., the presence of a long caudal peduncle (longer than the second dorsal fin base), and the original figures, it is clear that the species described by Sauvage is the same as that reported by Gaudant (1979) from the same locality. Gaudant (1979) interpreted †Paralates bleicheri as a gobiid and assigned it to the genus Pomatoschistus based on meristics.

Moreover, in 1981 Gaudant described another specimen of $†$ Paralates bleicheri from the sondage Niederhergheim, not far from Rouffach. This specimen has a slightly smaller anal (8 vs. 9 rays) and second dorsal fin (9 vs. 10 rays) and its frontals also differ in shape from those seen in the specimens from Rouffach. Thus this fish might not represent $\uparrow P a$. bleicheri and may need revision.

Range. Early Oligocene (Rupelian). 
TABLE 1. Meristic counts of all studied specimens of †Paralates. Numbers not in bold are subject to some uncertainty.

\begin{tabular}{|c|c|c|c|c|c|c|c|c|c|c|c|}
\hline \multirow[b]{2}{*}{ Specimen \# } & \multicolumn{6}{|c|}{ Oligocene of Rouffach, no. Ruf } & \multicolumn{5}{|c|}{$\begin{array}{l}\text { Upper Eocene of Isle of Wight } \\
\text { (Chapelcorner Fish Bed) }\end{array}$} \\
\hline & $6 a / b$ & 9_1 & 9_2 & 11/13_2 & $15 \mathrm{a} / \mathrm{b}$ & 18 & P 59784 & P 59785 & P 59786 & C 23632 & C 23633 \\
\hline $\begin{array}{l}\text { First dorsal fin } \\
\text { (D1) }\end{array}$ & - & - & $>V$ & - & VII & VII & VII & VII & VII & - & - \\
\hline $\begin{array}{l}\text { Second dorsal fin } \\
\text { (D2) }\end{array}$ & $\mathrm{I}, 10$ & 1,9 & 1,9 & 1,9 & $\mathrm{I}, 8$ & $\mathrm{I}, 10$ & 1,9 & $\mathrm{I}, 10$ & $>7$ & - & - \\
\hline Anal fin $(A)$ & 10 & $>8$ & 10 & $>7$ & $\mathrm{I}, 8$ & 1,8 & 1,8 & 1,9 & - & - & - \\
\hline $\begin{array}{l}\text { C (branched, } \\
\text { segmented) }\end{array}$ & 12 & 13 & $?$ & 13 & 12 & 12 & 12 & 13 & - & - & - \\
\hline $\begin{array}{l}\text { C (unbranched, } \\
\text { segmented) }\end{array}$ & & & & & & & $2+1$ or 2 & $2+2$ & & & \\
\hline $\begin{array}{l}\text { C (unbranched, } \\
\text { unsegmented) }\end{array}$ & & & & & & 7 & $10+?$ & $10+12$ & & & \\
\hline Ventral fin (V) & - & - & - & - & 1,5 & - & $\mathrm{I}, 5$ & I,5 & - & - & - \\
\hline Pectoral fin $(P)$ & - & $>11$ & 14 & $>9$ & 12 & - & $>14$ & 16 & $>11$ & $>13$ & $>9$ \\
\hline $\begin{array}{l}\text { Vertebrae } \\
\text { [postabdominal } \\
\text { vert.] }\end{array}$ & $\begin{array}{l}>23 \\
{[17]}\end{array}$ & $\begin{array}{l}>21 \\
{[16]}\end{array}$ & $>27$ & $\begin{array}{l}>23 \\
{[17]}\end{array}$ & $\begin{array}{c}29 \\
{[17]}\end{array}$ & $\begin{array}{c}30 \\
{[18]}\end{array}$ & $\begin{array}{c}30 \\
{[18]}\end{array}$ & $\begin{array}{c}31 \\
{[19]}\end{array}$ & $>23$ & $>11$ & $\begin{array}{c}29 \\
{[17]}\end{array}$ \\
\hline $\begin{array}{l}\text { Pterygiophore } \\
\text { formula D1 }\end{array}$ & - & - & - & - & - & - & - & $3-2121100$ & - & - & - \\
\hline
\end{tabular}

Occurrence. Southern Upper Rhine Graben (Rouffach, ?Niederhergheim; France).

†Paralates chapelcorneri n. sp.

Figures 3.2, 5, 6, 7, 8

zoobank.org/06A1F122-AF03-4481-8605-8C6107583C6A

1977 Gobius. - Ford: 109.

v 1988 Pomatoschistus(?) cf. bleicheri (Sauvage, 1883). - Gaudant and Quayle: 31-35, figs. 1316.

Material. Five articulated skeletons: NHMUK PV P 59784, NHMUK PV P 59785 (plus 59785_counterpart), NHMUK PV P 59786, SM C.23632, SM C.23633. These specimens served as the basis for this study. Further poorly preserved specimens are NHMUK PV P 59774, NHMUK PV P 59775, NHMUK PV P 59776, NHMUK PV P 59777, NHMUK PV P 59787, NHMUK PV P 59788, NHMUK PV P 59797. The specimens listed above represent the entire material of the species that is accessible.

Holotype. NHMUK PV P 59785 (part and counter part); specimen in lateral view; complete skeleton.

Type locality and horizon. Chapelcorner Fish Bed (Colenutt's bed 3), collected at King's Quay, southeast of East Cowes; Isle of Wight (UK); Upper Eocene (Priabonian).

Etymology. Named after the unit in which the fossils were found: Chapelcorner Fish Bed.
Diagnosis. Small fish up to about $35 \mathrm{~mm}$ in total length; body cylindrical; frontals relatively broad anteriorly in comparison to their posterior portions (width greater than $40 \%$ to that of the posterior section; see Figures 3.2, 5); seven spines in first dorsal fin; 30 to 31 vertebrae; 10 to 12 simple rays (= unbranched and unsegmented) in the caudal fin dorsally and ventrally; pterygiophore formula 32121100.

Description. For meristic characters and morphometric distances see Tables 1 and 2 .

The orbital region of the frontal bones is relatively broad (see Diagnosis and Figure 3.2). Other bones in the skull roof are not determinable.

The parasphenoid and basioccipital show a shape typical for gobiiform fishes. The parasphenoid is long and has a slender anterior and a broader posterior part. The basioccipital has a broad, roughly triangular shape and narrows posteriorly.

The premaxilla has a broad postmaxillary process, a smaller articular process and probably the spine-like ascending process, which seems premorse (Figure 5). Some conical teeth are visible. The maxilla is slender, with a thick articular head. The dentary is long and slender and bears conical teeth.

The shape of the palatine is not discernible. The ectopterygoid is slender and wedge-shaped. 
TABLE 2. Morphometrics of the genus †Paralates in $\mathrm{mm}$. Values standardized to standard length are given in brackets. Abbreviations: $A=$ anal fin, $C=$ caudal fin, $D 1=$ first dorsal fin, $D 2=$ second dorsal fin, $D 2 C=$ distance between end of $\mathrm{D} 2$ and first procurrent ray of $\mathrm{C}, \mathrm{P}=$ pectoral fin, $\mathrm{V}=$ pelvic fin.

\begin{tabular}{|c|c|c|c|c|c|c|}
\hline$\#$ & Ruf. 11/13_2 & Ruf. 15a/b & Ruf. 18 & P 59784 & P 59785 & P 59786 \\
\hline Total length & $29.1(115 \%)$ & $29.5(118 \%)$ & $34.5(119 \%)$ & $35.3(116 \%)$ & $22.5(116 \%)$ & $>22.3$ \\
\hline Standard length & 25.2 & 25.1 & 29.1 & 30.4 & 19.4 & $>22.3$ \\
\hline Max body height & $5.4(21.4 \%)$ & $5.4(21.5 \%)$ & $5.5(18.9 \%)$ & $5.9(19.4 \%)$ & $4.4(22.7 \%)$ & - \\
\hline Head length & $9.4(37.3 \%)$ & $6.9(27.5 \%)$ & $7.1(24.4 \%)$ & $9.5(31.3 \%)$ & $5.6(28.9 \%)$ & 6.6 \\
\hline Head height & $6.6(26.1 \%)$ & $5.4(21.5 \%)$ & $5.2(17.9 \%)$ & $6.9(22.7 \%)$ & $4.9(25.3 \%)$ & - \\
\hline $\begin{array}{l}\text { Horizontal eye } \\
\text { diameter }\end{array}$ & $1.5(5.9 \%)$ & $1.2(4.8 \%)$ & $1.3(4.5 \%)$ & - & $1.7(8.8 \%)$ & 1.4 \\
\hline Dist snout to D1 & $11.7(46.4 \%)$ & $9.2(36.7 \%)$ & $10.8(37.1 \%)$ & $11.7(38.5 \%)$ & $7.8(40.2 \%)$ & 7.9 \\
\hline Dist snout to D2 & $14.6(57.9 \%)$ & $14.5(57.8 \%)$ & $16.2(55.7 \%)$ & $17.4(57.2 \%)$ & $11.2(57.7 \%)$ & 12.8 \\
\hline Dist snout to $A$ & $15.8(62.7 \%)$ & 15.7 (62.5\%) & $16.5(56.7 \%)$ & $18.1(59.5 \%)$ & $11.5(59,3 \%)$ & 13.3 \\
\hline Dist snout to $P$ & $9.4(37,3 \%)$ & $8.7(34.7 \%)$ & - & $10.7(35.2 \%)$ & $6.8(35.1 \%)$ & 7.4 \\
\hline Dist snout to $\mathrm{V}$ & $9.2(36.5 \%)$ & $8.2(32.7 \%)$ & - & $10.6(34.9 \%)$ & $6.6(34.0 \%)$ & - \\
\hline Length D1 & $>2.1$ & $>2.4$ & $>2.4$ & $>3.4$ & $>1.7$ & - \\
\hline Length D2 & $2.8(11.1 \%)$ & $>2.4$ & $4.4(15.1 \%)$ & $>4.3$ & $>3.1$ & - \\
\hline Length A & $2.6(10.3 \%)$ & $>2.4$ & $>2.3$ & $>3.5$ & $>2.9$ & - \\
\hline Length $\mathrm{P}$ & $>0.8$ & $>1.3$ & - & $>1.9$ & $>0.8$ & $>2.8$ \\
\hline Length V & $>1.2$ & $>1.5$ & - & $>2.7$ & $2.7(13.9 \%)$ & - \\
\hline Base length $\mathrm{D} 1$ & $>0.6$ & $2.3(9.2 \%)$ & $2.3(7.9 \%)$ & $2.6(8.6 \%)$ & $1.6(8.2 \%)$ & - \\
\hline Base length D2 & $3.1(12.3 \%)$ & $3.0(12.0 \%)$ & $4.0(13.7 \%)$ & $>3.5$ & $2.4(12.4 \%)$ & - \\
\hline Base length $A$ & $3.0(11.9 \%)$ & $2.5(19.0 \%)$ & $3.7(12.7 \%)$ & $3.6(11.8 \%)$ & $1.9(9.8 \%)$ & - \\
\hline $\begin{array}{l}\text { Length caudal } \\
\text { peduncle }\end{array}$ & $6.3(25.0 \%)$ & $6.8(27.1 \%)$ & $8.9(30.6 \%)$ & $8.3(27.3 \%)$ & $5.7(29.4 \%)$ & - \\
\hline D2C & $6.7(26.6 \%)$ & $7.3(29.1 \%)$ & $8.4(28.6 \%)$ & $7.5(24.7 \%)$ & $5.0(25.8 \%)$ & - \\
\hline $\begin{array}{l}\text { Min height of caud } \\
\text { ped }\end{array}$ & $2.0(7.9 \%)$ & $1.7(6.8 \%)$ & $2.6(8.9 \%)$ & $3.0(9.7 \%)$ & $2.2(11.3 \%)$ & - \\
\hline Length of caudal fin & $3.8(15.1 \%)$ & $>3.8$ & $>5.0$ & $5.4(17.8 \%)$ & $3.6(18.6 \%)$ & - \\
\hline Length of vertebrae & $\begin{array}{c}0.5-0.6(1.9- \\
2.3 \%)\end{array}$ & $\begin{array}{c}0.6-0.7(2.4- \\
2.8 \%)\end{array}$ & $\begin{array}{c}0.6-0.8(2.1- \\
2.7 \%)\end{array}$ & $0.5-0.7(1.6-2.3 \%)$ & $0.4-0.5(2.1-2.6 \%)$ & $0.4-0.5$ \\
\hline
\end{tabular}

In one specimen (SM C.23632) bones bearing pharyngeal teeth of conical shape can be seen, which could correspond to ceratobranchial 5 and pharyngobranchial 3 . The ceratohyal shows a slender anterior and a broader posterior part, the epihyal (=posterior ceratohyal) is not preserved. The number of branchiostegals is six, of which the two slender anterior ones attach to the narrow anterior part of the ceratohyal.

The triangular opercle has cycloid scales on its upper part (Figure 5).

The vertebral column consists of (29?) 30-31 vertebrae with $18 ?-19$ post-abdominal vertebrae. There are at least seven rib pairs.
The pectoral fins have about 16 rays. The cleithrum is slightly curved, the supracleithrum is club-shaped (Figure 5). The post-temporal is Vshaped and has a process at the apex. Radials are present but not well-preserved.

The pelvic girdle is recognizable but badly preserved. The pelvic fins have one spine and five rays.

The first dorsal fin has seven spines, the second dorsal fin one spine and 10 rays. The pterygiophore formula of the first dorsal fin is 3-2121100.

The anal fin inserts slightly behind the second dorsal, and has one spine and eight rays.

The caudal endoskeleton consists of two triangular hypural plates (hypural plate $1+2$ and $3+4$, 

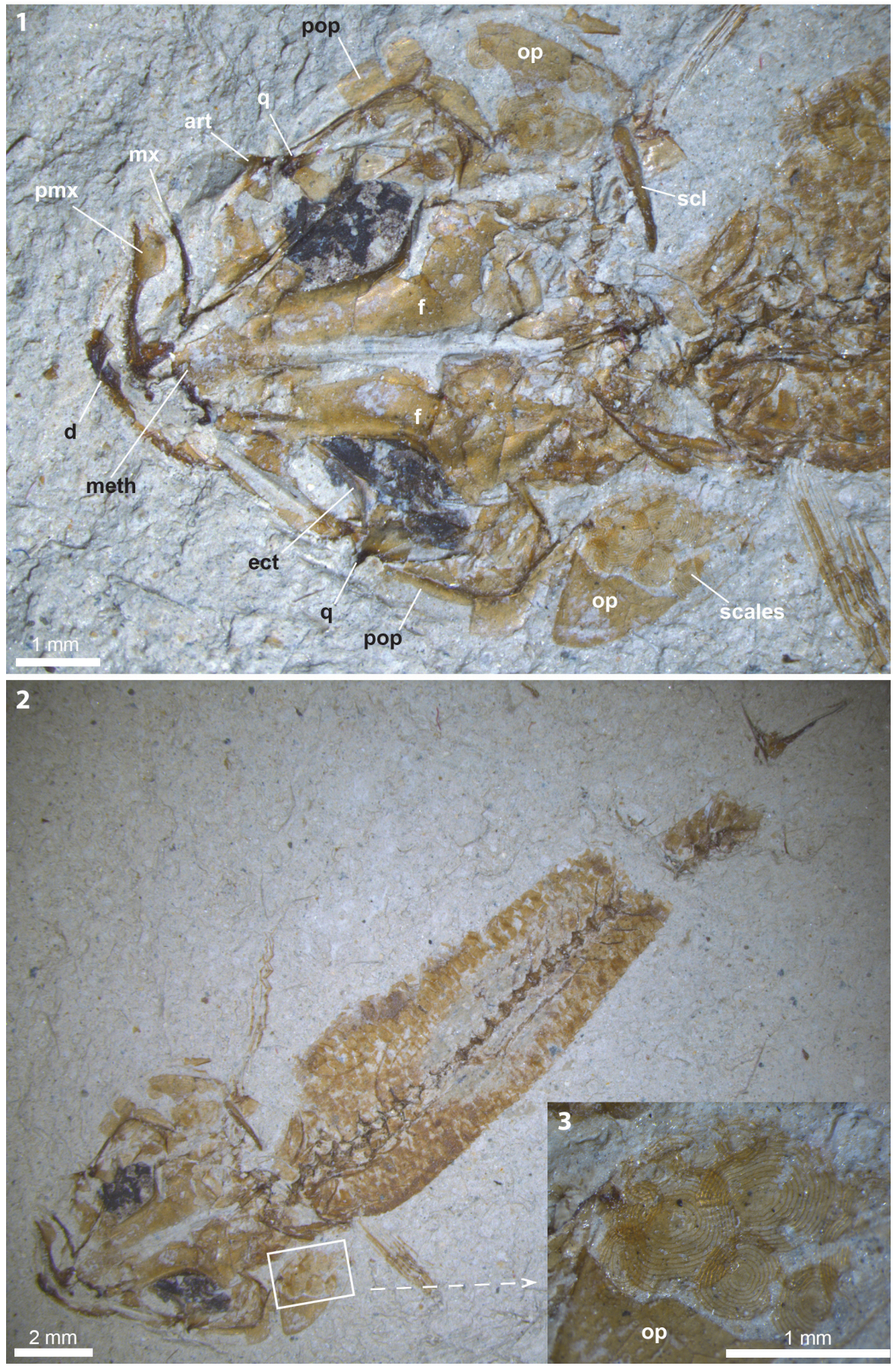

FIGURE 5. †Paralates chapelcorneri n. sp., NHMUK PV P 59786. 1. Skull. 2. Complete specimen. 3. Detail of opercle with cycloid scales. Abbreviations: art $=$ anguloarticular, $d=$ dentary, ect $=$ ectopterygoid, $f=$ frontal, meth $=$ mesethmoid,$m x=$ maxilla,$o p=$ opercle,$p m x=$ premaxilla, $p o p=$ preopercle,$q=$ quadrate, $\mathrm{scl}=$ supracleithrum .

see Figure 7). The upper one is fused to the terminal centrum. Hypural 5 is small and splint-like. The parhypural is slender and as long as the lower margin of hypural $1+2$. At least one epural is present. The caudal fin has 12 or 13 segmented and branched rays, and one to two segmented and unbranched rays, dorsally and ventrally. There are 10 to 12 simple rays (=unbranched and unsegmented) dorsally and 12 ventrally [caudal fin formula according to the scheme of Fricke (1983) in specimen NHMUK PV P 59785_counterpart: (x), ii, 13, ii, (xii), see Figure 7]. 

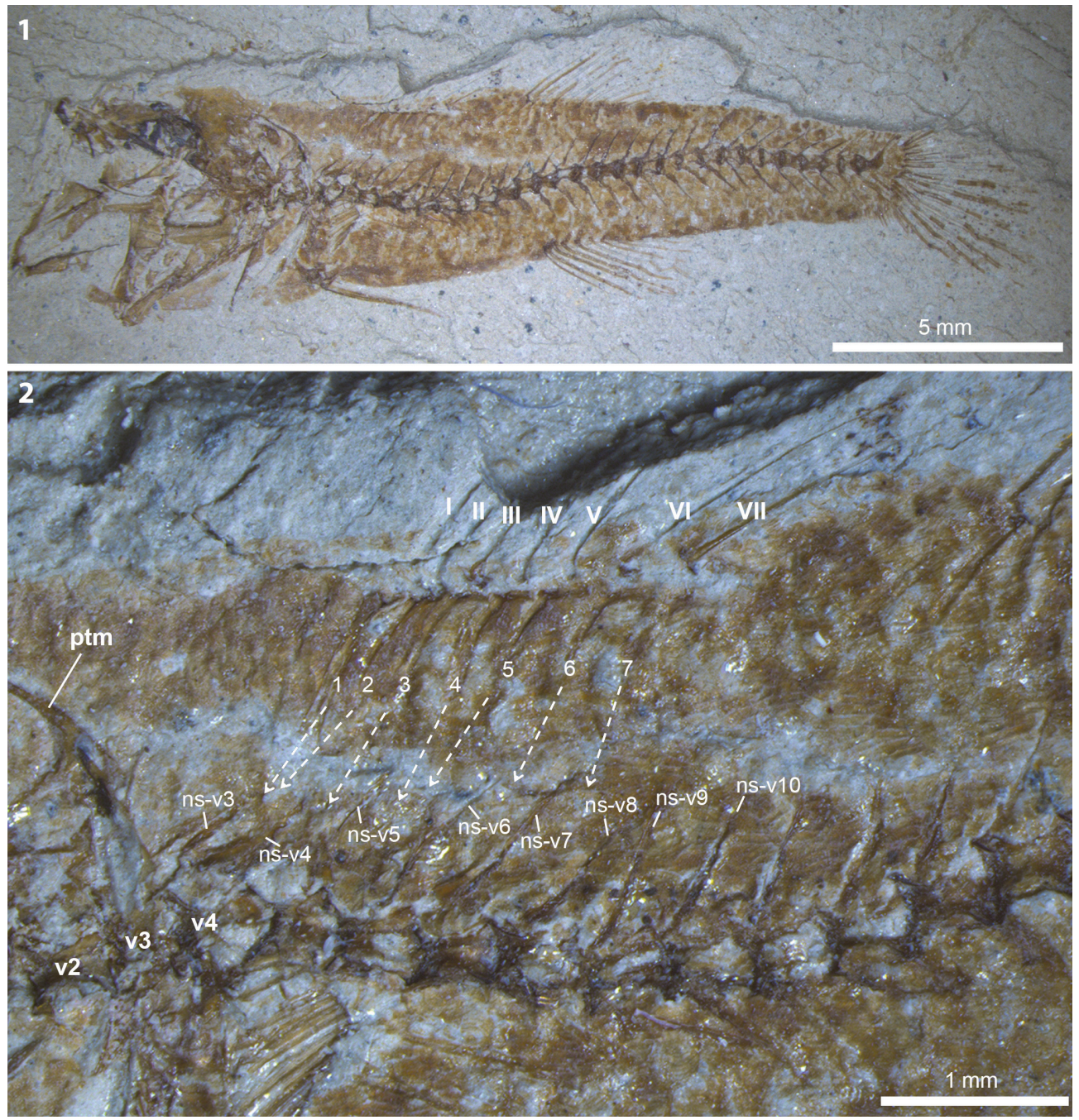

FIGURE 6. †Paralates chapelcorneri n. sp., NHMUK PV P 59785. 1. Complete specimen. 2. Region of the first dorsal fin. Arrows point from the pterygiophores to the interneural spaces into which each inserts. Pterygiophore formula $=$ 3-2121100 The spinous rays of the first dorsal fin are marked with roman numerals. Abbreviations: $1-7=$ pterygiophores, ptm = post-temporal, ns-v3-10 = neural spines of vertebrae 3-10, v2-4 = vertebral centra 2-4.

The squamation consists of cycloid scales on the opercle and ctenoid scales on the rest of the body.

Remark. The meristic data for the specimens from Rouffach are rather similar to that for the fishes from the Isle of Wight (see Table 1), as is the long caudal peduncle, and we therefore place the species †Paralates chapelcorneri n. sp. in the same genus as $\dagger P$. bleicheri.

$\dagger$ Paralates chapelcorneri n. sp. from the Isle of Wight is different from $† P a$. bleicheri from Rouffach for two reasons:

(1) In † Pa. chapelcorneri n. sp. the supraorbital part of the frontals is clearly broader than in the Rouffach fishes (see Figure 3.2 vs. 3.1). In NMB Ruf. 13 the width in the supraorbital part
$(0.63 \mathrm{~mm})$ is $22 \%$ of the width in the posterior part $(2.86 \mathrm{~mm})$; in NHMUK PV P 59786 from England it is $40 \%(0.71 \mathrm{~mm}$ vs. $1.77 \mathrm{~mm})$. Also Gaudant and Quayle (1988: 32) mentioned that the supraorbital part of the frontal is relatively broad in NHMUK PV P 59786 (now $+P a$. chapelcorneri n. sp.). Although the specimen of $\dagger P a$. chapelcorneri n. sp. shown in Figure 3.2 is more dorso-ventrally compressed than the specimen of $\mathrm{Pa}$. bleicheri shown in Figure 3.1, the shapes of their frontals are different and this cannot be explained by differences in preservation alone.

(2) †Paralates chapelcorneri n. sp. has more unbranched and unsegmented rays in the caudal fin (at least 10 vs. maximal seven). 

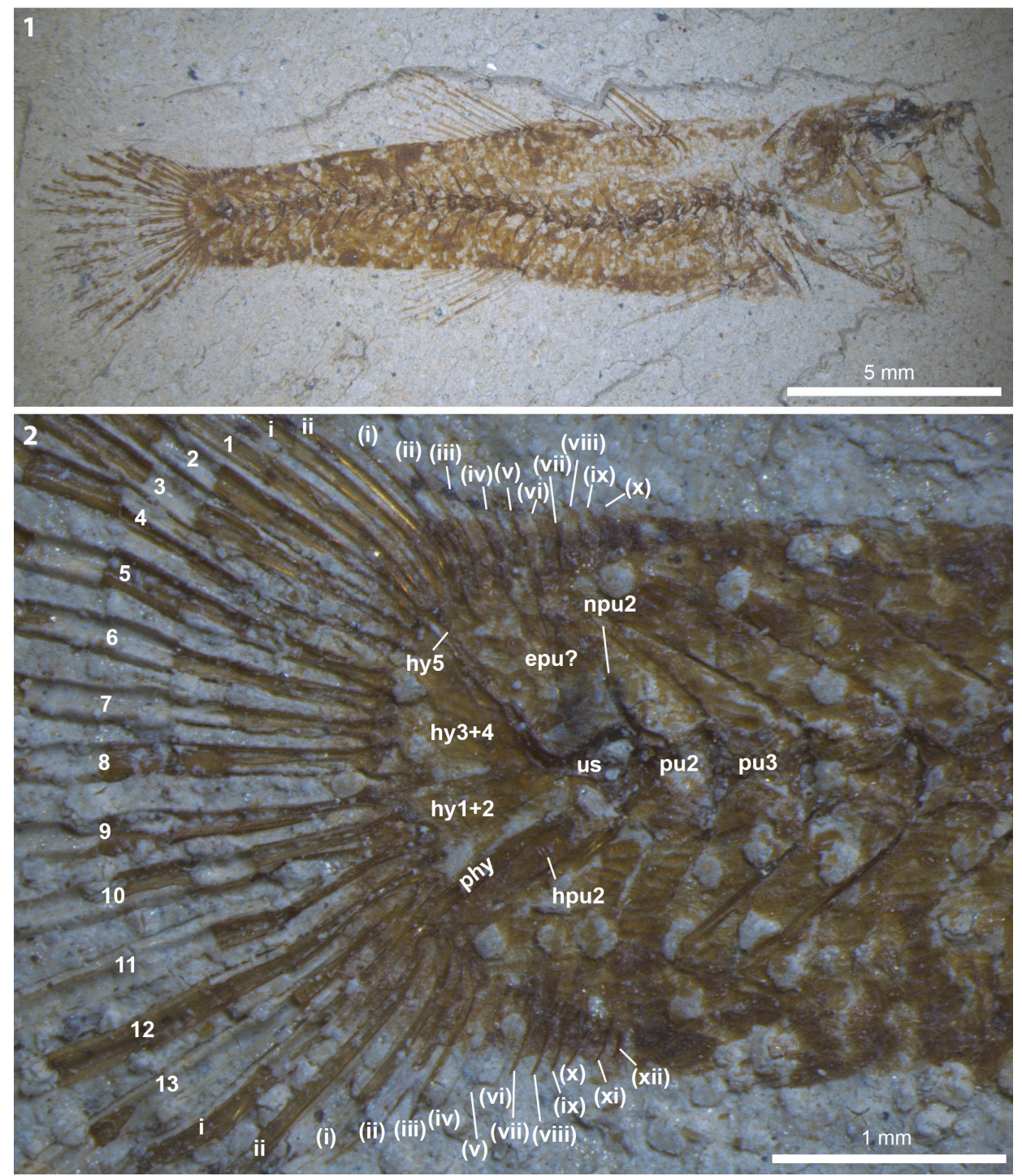

FIGURE 7. †Paralates chapelcorneri n. sp., NHMUK PV P59785_counterpart. 1. Complete specimen. 2. Caudal skeleton and fin. Small Roman numerals in parentheses label unbranched, unsegmented rays, small Roman numerals indicate segmented unbranched rays, and Arabic numerals designate segmented, branched rays (after Fricke, 1983). Abbreviations: epu = epural, $\mathrm{hpu}=$ hemal spine of preural centrum, hy = hypural, $\mathrm{npu}=$ neural spine of preural centrum, phy = parhypural, $\mathrm{pu}=$ preural centrum, us $=$ urostyle.

\section{DISCUSSION}

The specimens re-examined here display certain features, which clearly show that they belong neither to Pomatoschistus nor even to the Oxudercidae (see below).

\section{Assignment to the Gobiiformes}

The fishes from both localities are members of the Gobiiformes because they exhibit the following features (see Springer, 1983; Johnson and Brothers, 1993; Winterbottom, 1993; Wiley and Johnson, 2010): suspensorium fenestrae are large
(Figure 8) (Gosline, 1955; see for illustration Parmentier et al., 2013, figure $4 \mathrm{~A}$ ); hypurals 1 and 2 are fused; hypurals 3 and 4 are fused to each other and to the urostyle (Figure 7); parietals are absent.

\section{Relationship to Pomatoschistus?}

Pomatoschistus is a member of the 'sandgoby' group among the Oxudercidae (Agorreta et al., 2013). The 'sand-gobies' have been defined as a distinct clade based on morphological characters by McKay and Miller (1997). This clade has additionally been confirmed based on molecular work 

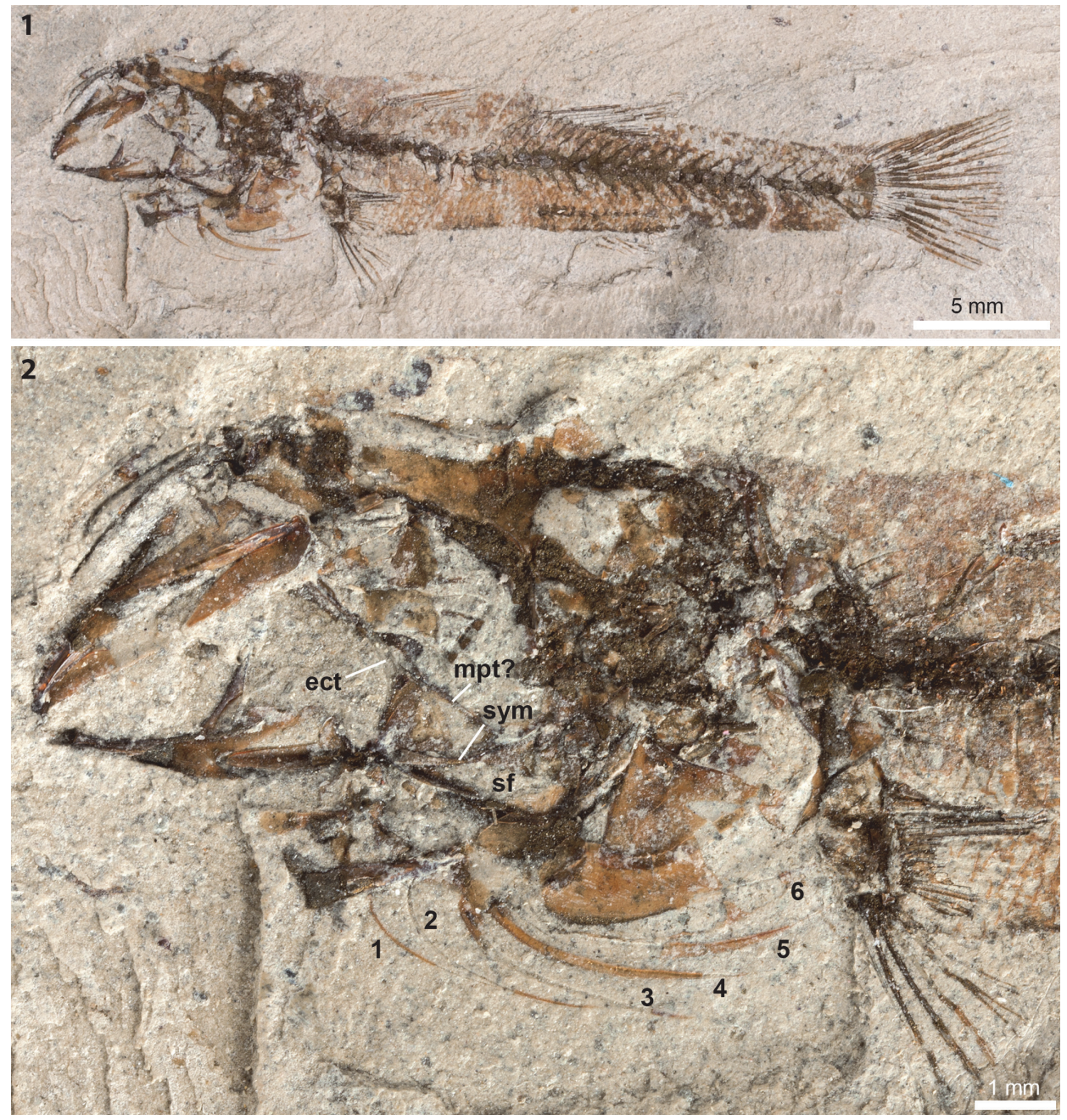

FIGURE 8. †Paralates chapelcorneri n. sp., NHMUK PV P 59784. 1. Complete specimen. 2. Skull showing possible symplectic and six branchiostegals. Abbreviations: 1-6 = branchiostegals, ect $=$ ectopterygoid, $\mathrm{mpt}=$ metapterygoid, sf = suspensorium fenestra, sym = symplectic. (Photos by K. Webb; $@$ The Trustees of the Natural History Museum, London)

(see McKay and Miller, 1997; Agorreta et al., 2013; Thacker, 2013).

The informal name 'sand goby' refers to the preferred occurrence of these fishes on sandy substrates; no formal name exists for this clade. The group comprises the genus Pomatoschistus, together with Gobiusculus, Knipowitschia, Economidichthys and Hyrcanogobius (see McKay and Miller, 1997; Agorreta et al., 2013). The 'sand gobies' show a distinctive feature in the jaws: the absence of a postmaxillary process on the premaxilla, except in some females of Gobiusculus flavescens (McKay and Miller, 1997). Other oxudercids, most gobiids, as well as the members of the families with six branchiostegals (see Figure 1 ), possess such a postmaxillary process (McKay and Miller, 1997). Moreover, McKay and Miller
(1997) found that the pterygiophore formula in the 'sand gobies' starts with (12...) and that there is more than one interneural space.

A postmaxillary process on the premaxilla is present in both species of $†$ Paralates (see Figures $2.1,5.1$ ). Additionally, the pterygiophore formula is discernible in the specimen NHMUK PV P 59785 of †Paralates chapelcorneri n. sp. (Figure 6.2) and starts with $(21 \ldots)$. We therefore conclude that †Paralates is clearly different from the genus Pomatoschistus and not a member of the 'sand gobies'.

Moreover, $\uparrow$ Paralates is not a member of the Gobiidae or Oxudercidae, because it has six branchiostegals. Gaudant and Quayle (1988) mentioned the presence of an entopterygoid, which would provide an additional criterion for exclusion 
TABLE 3. Meristic characters of recent gobioid taxa for which the pterygiophore formula 3-212110(0) has been observed in at least one species of the genus. The number of caudal fin rays refers to all segmented rays (branched and unbranched). Abbreviations: $A=$ anal fin, $C=$ caudal fin, $D 1=$ first dorsal fin, $D 2=$ second dorsal fin, $P=$ pectoral fin, $V=$ pelvic fin.

\begin{tabular}{|c|c|c|c|c|c|c|c|c|c|}
\hline Taxon & D1 & D2 & A & C & V & $\mathbf{P}$ & $\begin{array}{l}\text { Vertebrae } \\
\text { [postabd] }\end{array}$ & Source & Family \\
\hline $\begin{array}{l}\text { †Paralates bleicheri } \\
\text { Sauvage, } 1883\end{array}$ & VII & $\mathrm{I}, 10$ & 1,9 & $>12-13$ & 1,5 & 14 & $\begin{array}{c}29 \\
{[17-18 ?]}\end{array}$ & this study & inc. sed. \\
\hline $\begin{array}{l}\text { †Paralates } \\
\text { chapelcorneri n. sp. }\end{array}$ & VII & $\mathrm{I}, 10$ & I,8-9 & $14-17$ & I,5 & $14-16$ & $\begin{array}{c}30 ?-31 \\
{[18 ?-19]}\end{array}$ & this study & inc. sed. \\
\hline $\begin{array}{l}\text { Gobiodon okinawae } \\
\text { Sawada, Arai \& Abe, } \\
1972\end{array}$ & VI & $\mathrm{I}, 10$ & 1,9 & 15 & - & - & $\begin{array}{c}27 \\
{[17]}\end{array}$ & $\begin{array}{l}\text { unpublished } \\
\text { data }\end{array}$ & Gobiidae \\
\hline $\begin{array}{l}\text { Gobiosoma } \\
\text { hemigymnum } \\
\text { (Eigenmann and } \\
\text { Eigenmann 1888) }\end{array}$ & VII & $\mathrm{I}, 11$ & 1,9 & 17 & 1,5 & $17-19$ & $\begin{array}{c}27 \\
{[16]}\end{array}$ & $\begin{array}{c}\text { van Tassell et al. } \\
2015\end{array}$ & Gobiidae \\
\hline Gobiosoma spp. & - & - & - & - & - & - & $\begin{array}{c}27-28 \\
{[15-17]}\end{array}$ & $\begin{array}{c}\text { Birdsong et al. } \\
1988\end{array}$ & Gobiidae \\
\hline Gobulus spp. & - & - & - & - & - & - & $\begin{array}{c}27-28 \\
{[16-17]}\end{array}$ & $\begin{array}{c}\text { Birdsong et al. } \\
1988\end{array}$ & Gobiidae \\
\hline Gobulus spp. & VII-VIII & $1,9-13$ & $\mid, 7-13$ & $15-17$ & 1,5 & $15-18$ & $\begin{array}{c}27-28 \\
{[16-17]}\end{array}$ & $\begin{array}{c}\text { Hoese and } \\
\text { Reader } 2001\end{array}$ & Gobiidae \\
\hline $\begin{array}{l}\text { Gobiomorphus } \\
\text { alpinus Stokell, } 1962\end{array}$ & III-VII & I,7-9 & $\mathrm{I}, 8-10$ & - & - & $16-19$ & $29-31$ & McDowall 1994 & Eleotridae \\
\hline Gobiomorphus spp. & III-VIII & $\mathrm{I}, 7-10$ & $\mathrm{I}, 7-10$ & - & - & $13-21$ & $27-31$ & McDowall 1975 & Eleotridae \\
\hline Gobiomorphus spp. & - & - & - & - & - & - & $\begin{array}{c}28-31 \\
{[16-19]}\end{array}$ & $\begin{array}{c}\text { Birdsong et al. } \\
1988\end{array}$ & Eleotridae \\
\hline Thalasseleotris & & & & 16 & & & $\begin{array}{c}27 \\
{[17]}\end{array}$ & $\begin{array}{l}\text { Hoese and } \\
\text { Larson } 1987\end{array}$ & Thalasseleotrididae \\
\hline
\end{tabular}

of the fossil from the Gobiidae and Oxudercidae. However, the bone depicted as an entopterygoid by Gaudant and Quayle (1988) is not positioned near the ectopterygoid (as would be expected), and its anatomical assignment is therefore difficult to verify; it may be the distorted metapterygoid. The long caudal peduncle, which is longer than the base of the second dorsal fin, may also argue for an assignment to the "non-Gobiidae" (see Murdy et al., 2002).

\section{Affinity of $\dagger$ Paralates to Previously Described Gobiiform Fossils}

One feature that clearly differentiates $†$ Paralates from other fossil Gobiiformes is the number of spinous rays in the first dorsal fin. The only previously described species that has a first dorsal fin with seven spines is the Oligocene species †Pirskenius radoni Prikryl, 2014. However, the genus †Pirskenius is also characterized by seven branchiostegal rays (Obrhelová, 1961; Prikryl, 2014) whereas only six branchiostegal rays are present in †Paralates.
A few fossil gobiiforms with six branchiostegal rays have been described, i.e., $\dagger$ Lepidocottus aries (Agassiz, 1839) (see Gierl et al., 2013), †L. papyraceus (Agassiz, 1839) (see Pandolfi et al., 2016), $\dagger$ Eleogobius brevis (Agassiz, 1839) and $\dagger E$. gaudanti Gierl and Reichenbacher, 2015. Whereas the species of †Lepidocottus have only 25-26 vertebrae, the two known species of †Eleogobius Gierl and Reichenbacher, 2015 from the lower Miocene of S. Germany, like †Paralates, have 29-31. However, in †Eleogobius the D2C can sometimes be slightly longer than the base of D2 (Gierl and Reichenbacher, 2015), while †Paralates has a very long $\mathrm{D} 2 \mathrm{C}$ that is about twice the length of the base of D2 (see Table 3).

Further species with large numbers of vertebrae compared to †Paralates include †Gobius multipinnatus (Meyer, 1852) from the lower Miocene of Germany and Pomatoschistus sp. from the upper Miocene of the North Caucasus, Russia. Also these species, however, clearly differ from †Paralates: $\dagger G$. multipinnatus has a bigger second dorsal fin (D2) (I+12-13 vs. I+10 in †Paralates) and the 
length of the base of D2 exceeds D2C (see Gierl and Reichenbacher, 2015). Pomatoschistus sp., besides being younger (middle Miocene), has bigger anal and dorsal fins (see Carnevale et al., 2006).

\section{Phenotypic Affinity of $†$ Paralates to the Extant Eleotrid Gobiomorphus}

The pterygiophore formula 3-2121100 seen in †Paralates has been described (albeit with only one interneural space) in a few members of the Gobiidae, Thalasseleotrididae, and Eleotridae (see Birdsong et al., 1988). This specific formula, however, occurs only in genera that show some polymorphism with regard to the pterygiophore formula, e.g., in Gobiomorphus, Gobiosoma, Gobulus, Gobiodon, and Thalasseleotris (see Table 3). In addition, it is never the 'normal case' but always exceptional (see Hoese and Larson, 1987; Birdsong et al., 1988; Lee 1993; our unpublished data). However, those genera of the Gobiidae and Thalasseleotrididae for which a pterygiophore formula 3-212110 has been reported always have more or fewer vertebrae than are seen in †Paralates (Hoese and Larson, 1987; Birdsong et al., 1988; Lee 1993; our unpublished data) (see Table 3 ). Only the eleotrid genus Gobiomorphus reveals six branchiostegals (like in $\uparrow$ Paralates) and a similar combination of the pterygiophore formula and vertebrae count as seen in †Paralates: The pterygiophore formula is 3-212110 (vs. 3-2121100) and the number of vertebrae is $12+19$ (vs. $12+17-19$ ).

Species of Gobiomorphus are now restricted to coastal rivers of Eastern Australia and rivers and lakes in New Zealand (Hoese and Larson, 1987). Among the Gobiiformes, Gobiomorphus is difficult to define based on meristic and osteological characters because it belongs to the genera with the highest levels of variation in skeletal features (see McDowall, 1975; Hoese and Larson, 1987; Birdsong et al., 1988). For instance, the ectopterygoid is present in some species, and lacking in others (Hoese, 1984; Hoese and Larson, 1987), the epural number varies between 1 and 2 (see Birdsong et al., 1988) and the number of vertebrae (excluding the terminal centrum) ranges from 26 to 31 (McDowall, 1975). Nonetheless, the genus Gobiomorphus has been recognized as monophyletic based on molecular and morphological data (see McDowall, 1975; Stevens and Hicks, 2009).

Skeletons of Gobiomorphus-like fossils have been described from the Miocene of New Zealand: †Mataichthys bictenatus Schwarzhans et al., 2012 has a lower vertebral count (28) and a smaller anal fin (I+7) (see Schwarzhans et al., 2012) than seen in †Paralates. Gobiomorphus sp. (described in McDowall et al., 2006) also has fewer vertebrae (26-28), and the count of its rays in the caudal fin falls into the range of $†$ Paralates. Most other counts are uncertain, due to the moderate preservation of the fossils. So it is hard to say if there is a relationship between the fossil Gobiomorphus sp. from New Zealand and †Paralates, in spite of the similarities between the latter and extant Gobiomorphus species.

\section{Conclusions}

The question remains whether 'sand gobies' are represented in the fossil record. A specimen determined as "Pomatoschistus cf. bleicheri" from the lower Miocene of Bergama (Turkey) was described (Rückert-Ülkümen, 2000), but the description given makes it hard to accept the proposed assignment ( 7 branchiostegals; only 27 vertebrae). The only reliable records of 'sand goby' skeletons seem to be Pomatoschistus sp. (with otoliths in situ) from the upper Miocene of the North Caucasus (Russia) described in Carnevale et al. (2006) and the species described in Schwarzhans et al. (2017) from the middle Miocene (Sarmatian) of the Central Paratethys (Croatia). Besides, there are some otolith-based species of the 'sand gobies' from the middle Miocene (see Weiler, 1943; Wienrich et al., 2009; Schwarzhans, 2010, 2014; Bratishko et al., 2015; Schwarzhans et al., 2015; Schwarzhans et al., 2017).

For now, the oldest member of modern Gobiiformes with five branchiostegals in the fossil record is the gobiid †Gobius jarosi Prikryl and Reichenbacher, 2017 in Reichenbacher et al. (2017) from the lower Miocene of Central Europe (Czech Republic). Phylogenetic analyses based on a combination of morphology, and molecular data will be necessary to more accurately understand the phylogenetic relationships of the many different extant and extinct gobiiform fishes from Europe.

\section{ACKNOWLEDGEMENTS}

We would like to thank E. Bernard (NHMUK, London, UK), M. Riley (Sedgwick Museum, Cambridge, UK), and L. Costeur (NMB, Basel, Switzerland) for their kind support with the loan of the specimens described here. We are grateful for the UV pictures provided by $\mathrm{H}$. Tischlinger and the photographs made by $\mathrm{M}$. Schellenberger and $\mathrm{K}$. Webb. We also acknowledge the constructive comments of D. Erpenbeck (LMU Munich, Germany), two anonymous reviewers, and the editorial crew 
of PE. This work was funded by a grant from the Deutsche Forschungsgemeinschaft (RE 1113/201).

\section{REFERENCES}

Agassiz, L. 1833-1843. Recherches sur les Poissons fossiles. Tome IV. Petitpierre, Neuchâtel.

Agorreta, A., San Mauro, D., Schliewen, U., Van Tassell, J.L., Kovačić, M., Zardoya, R., and Rüber, L. 2013. Molecular phylogenetics of Gobioidei and phylogenetic placement of European gobies. Molecular Phylogenetics and Evolution, 69(3):619-633.

Bajpai, S. and Kapur, V.V. 2004. Oldest known gobiids from Vastan Lignite Mine (early Eocene), Surat district, Gujarat. Current Science, 87(4):433-435.

Bannikov, A.F. and Carnevale, G. 2016. †Carlomonnius quasigobius gen. et sp nov.: the first gobioid fish from the Eocene of Monte Bolca, Italy. Bulletin of Geosciences, 91(1):13-22.

Birdsong, R.S., Murdy, E.O., and Pezold, F.L. 1988. A study of the vertebral column and median fin osteology in gobioid fishes with comments on gobioid relationships. Bulletin of Marine Science, 42(2):174-214.

Bratishko, A., Schwarzhans, W., Reichenbacher, B., Vernyhorova, Y., and Ćorić, S. 2015. Fish otoliths from the Konkian (Miocene, early Serravallian) of Mangyshlak (Kazakhstan): testimony to an early endemic evolution in the Eastern Paratethys. Paläontologische Zeitschrift, 89(4):839-889.

Carnevale, G., Bannikov, A.F., Landini, W., and Sorbini, C. 2006. Volhynian (early Sarmatian sensu lato) fishes from Tsurevsky, North Caucasus, Russia. Journal of Paleontology, 80(4):684-699.

Eigenmann, C.H. and Eigenmann, R.S. 1888. A list of the American species of Gobiidae and Callionymidae, with notes on the specimens contained in the Museum of Comparative Zoölogy, at Cambridge, Massachusetts. Proceedings of the California Academy of Sciences. Second Series, 1(1):51-78.

Ford, R.L.E. 1977. A genus of fossil fish (Gobius) new to the Isle of Wight. Proceedings of the Isle of Wight Natural History and Archeological Society, 7(2):109110.

Förster, B. 1913. Die Versteinerungen aus den Tiefbohrungen auf Kali im Oligocän des Oberelsass. Mitteilungen der Geologischen Landesanstalt von Elsaß-Lothringen, 8(1):1-49.

Fricke, R. 1983. A method for counting caudal fin rays of actinopterygian fishes. Braunschweiger Naturkundliche Schriften, 1(4):729-733.

Gaudant, J. 1979. Sur la présence de Gobiidae (Poissons téléostéens) dans l'Oligocène inférieur de Rouffach (Haut-Rhin). Sciences Géologiques Bulletin, 32(3):131-137.

Gaudant, J. 1981. Nouvelles recherches sur l'ichthyofaune des Zones salifères moyenne et supérieure (Oligocène inférieur) du bassin potassique alsacien. Sciences Géologiques Bulletin, 34(4):209-218.
Gaudant, J. 1996. Mise en évidence des plus anciens Gobioidei (Poissons téléostéens) connus dans le Lutétien inférieur marin de Catalogne (Espagne). Comptes Rendus de l'Académie des Sciences. Série II, Sciences de la Terre et des Planètes, 322(1):7176.

Gaudant, J. and Quayle, W.J. 1988. New palaeontological studies on the Chapelcorner fish bed (Upper Eocene, Isle of Wight). Bulletin of the British Museum of Natural History (Geology), 44(1):15-39.

Gierl, C. and Reichenbacher, B. 2015. A new fossil genus of Gobiiformes from the Miocene characterized by a mosaic set of characters. Copeia, 103(4):792-805.

Gierl, C., Reichenbacher, B., Gaudant, J., Erpenbeck, D., and Pharisat, A. 2013. An extraordinary gobioid fish fossil from southern France. PLOS ONE, 8(5):e64117.

Gill, A.C. and Mooi, R.D. 2012. Thalasseleotrididae, new family of marine gobioid fishes from New Zealand and temperate Australia, with a revised definition of its sister taxon, the Gobiidae (Teleostei: Acanthomorpha). Zootaxa, 3266:41-52.

Gosline, W.A. 1955. The osteology and relationships of certain gobioid fishes, with particular reference to the genera Kraemeria and Microdesmus. Pacific Science, IX:158-170.

Günther, A.C.L.G. 1880. An Introduction to the Study of Fishes. Adam and Charles Black, Edinburgh.

Hoese, D.F. 1984. Gobioidei: relationships, p. 588-591. In Moser, H. G., Richards, W. J., Cohen, D. M., Fahay, M. P., Kendall, Jr., A. W., Richardson, S. L. (eds.), Ontogeny and Systematics of Fishes. American Society of Ichthyologists and Herpetologists, Gainesville, Florida.

Hoese, D.F. and Gill, A.C. 1993. Phylogenetic relationships of eleotridid fishes (Perciformes, Gobioidei). Bulletin of Marine Science, 52(1):415-440.

Hoese, D.F. and Larson, H.K. 1987. New Australian fishes. Part 11. A new genus and species of eleotridid (Gobioidei) from Southern Australia with a discussion of relationships. Memoirs of the Museum of Victoria, 48(1):43-50.

Hoese, D.F. and Reader, S. 2001. Revision of the eastern Pacific species of Gobulus (Perciformes: Gobiidae), with description of a new species. Revista De Biologia Tropical, 49 (Supplement 1):169-176.

Johnson, G.D., and Brothers, E.B. 1993. Schindleria: a paedomorphic goby (Teleostei, Gobioidei). Bulletin of Marine Science, 52(1):441-471.

Johnson, G.D., and Patterson, C. 1993. Percomorph phylogeny: a survey of acanthomorphs and a new proposal. Bulletin of Marine Science, 52(1):554-626.

Lee, Y.-J. 1993. Study of vertebral column and pterygiophores in Gobiidae (Pisces, Perciformes) from Korea. The Korean Journal of Systematic Zoology, 9(1):25-34.

Maïkovsky, V. 1941. Contribution à l'étude paléontologique et startigraphique du bassin potassique 
d'Alsace. Mémoires du Service de la Carte Géologique d'Alsace et de Lorraine, 6:1-192.

McDowall, R.M. 1975. A revision of the New Zealand species of Gobiomorphus (Pisces: Eleotridae). National Museum of New Zealand Records, 1(1):132.

McDowall, R.M. 1994. The Tarndale bully, Gobiomorphus alpinus Stokell (Pisces: Eleotridae) revisited and redescribed. Journal of the Royal Society of New Zealand, 24(1):117-124.

McDowall, R.M., Kennedy, E.M., Lindqvist, J.K., Lee, D.E., Alloway, B.V., and Gregory, M.R. 2006. Probable Gobiomorphus fossils from the Miocene and Pleistocene of New Zealand (Teleostei: Eleotridae). Journal of the Royal Society of New Zealand, 36(3):97-109.

McKay, S.I. and Miller, P.J. 1997. The affinities of European sand gobies (Teleostei: Gobiidae). Journal of Natural History, 31(10):1457-1482.

Meyer, H.v. 1852. Fossile Fische aus dem Tertiärthon von Unter-Kirchberg an der Iller. Palaeontographica. Beiträge zur Naturgeschichte der Vorwelt, 2(Dritte Lieferung):85-113.

Miller, P.J. 1973. The osteology and adaptive features of Rhyacichthys aspro (Teleostei: Gobioidei) and the classification of gobioid fishes. Journal of Zoology, 171(3):397-434.

Murdy, E.O., Hoese, D.F., and Thacker, C.E. 2002. Suborder Gobioidei, p. 1778-1798. In Carpenter, K.E. (ed.), FAO species identification guide for fishery purposes. The living marine resources of the Western Central Atlantic. Volume 3: Bony fishes part 2 (Opistognathidae to Molidae), sea turtles and marine mammals. FAO Species Identification Guide for Fishery Purposes and American Society of Ichthyologists and Herpetologists Special Publication No. 5. Food and Agriculture oorganization of the United Nations, Rome.

Nelson, J.S., Grande, T.C., and Wilson, M.V.H. 2016. Fishes of the World, Fifth Edition. John Wiley \& Sons, Inc., Hoboken, New Jersey.

Obrhelová, N. 1961. Vergleichende Osteologie der tertiären Süsswasserfische Böhmens (Gobioidei). Sborník Ústředního ústavu geologického: oddil paleontologiyký, 26:103-192.

Pandolfi, L., Carnevale, G., Costeur, L., Del Favero, L., Fornasiero, M., Ghezzo, E., Maiorino, L., Mietto, P., Piras, P., Rook, L., Sansalone, G., and Kotsakis, T. 2016. Reassessing the earliest Oligocene vertebrate assemblage of Monteviale (Vicenza, Italy). Journal of Systematic Palaeontology:1-45.

Parmentier, E., Kéver, L., Boyle, K., Corbisier, Y.E., Sawelew, L., and Malavasi, S. 2013. Sound production mechanism in Gobius paganellus (Gobiidae). The Journal of Experimental Biology, 216(17):31893199.

Patzner, R.A., Van Tassell, J.L., Kovačić, M., and Kapoor, B.G. (eds.) 2011. The biology of gobies. Science Publishers Inc., Enfield, NH.
Prikryl, T. 2014. A new species of the sleeper goby (Gobioidei, Eleotridae) from the České Středohoří Mountains (Czech Republic, Oligocene) and analysis of the validity of the family Pirskeniidae. Paläontologische Zeitschrift, 88(2):187-196.

Rasband, W.S. 1997-2016. ImageJ. U.S. National Institutes of Health, Bethesda, Maryland, USA.

Reichenbacher, B., Gregorová, R., Holcová, K., Šanda, R., Vukić, J., and Prikryl, T. 2017. Discovery of the oldest Gobius (Teleostei, Gobiiformes) from a marine ecosystem of Early Miocene age. Journal of Systematic Palaeontology. doi: 10.1080/14772019.2017.1313323

Rückert-Ülkümen, N. 2000. Eine neue Fisch-Fauna aus dem Tertiär von Bergama (West-Türkei). Mitteilungen der Bayerischen Staatssammlung für Paläontologie und Historische Geologie, 40:153-163.

Sauvage, M.H.E. 1883. Notes sur les poissons fossiles. Bulletin de la Société Géologique de France, 3(11):475-503.

Sawada, Y., Arai, R., and Abe, T. 1972. Gobiodon okinawae, a new coral-goby from the Ryukyu Islands, Japan. Japanese Journal of Ichthyology, 19(2):5762.

Schwarzhans, W. 2010. The Otoliths from the Miocene of the North Sea Basin. Backhuys Publishers, Leiden \& Margraf Publishers, Weikersheim.

Schwarzhans, W. 2014. Otoliths from the middle Miocene (Serravallian) of the Karaman Basin, Turkey. Cainozoic Research, 14(1):35-69.

Schwarzhans, W., Ahnelt, H., Carnevale, G., Japundžić, S., Bradić, K., and Bratishko, A. 2017. Otoliths in situ from Sarmatian (Middle Miocene) fishes of the Paratethys. Part III: tales from the cradle of the PontoCaspian gobies. Swiss Journal of Palaeontology, 136(1):45-92.

Schwarzhans, W., Bradić, K., and Rundić, L. 2015. Fishotoliths from the marine-brackish water transition from the Middle Miocene of the Belgrade area, Serbia. Paläontologische Zeitschrift, 89(4):815-837.

Schwarzhans, W., Scofield, R.P., Tennyson, A.J.D., Worthy, J.P., and Worthy, T.H. 2012. Fish remains, mostly otoliths, from the non-marine early Miocene of Otago, New Zealand. Acta Palaeontologica Polonica, 57(2):319-350.

Springer, V.G. 1983. Tyson belos, new genus and species of Western Pacific fish (Gobiidae, Xenisthminae), with discussions of gobioid osteology and classification. Smithsonian Contributions to Zoology, 390. Smithsonian Institution Press, Washington, D. C.

Stevens, M.I. and Hicks, B.J. 2009. Mitochondrial DNA reveals monophyly of New Zealand's Gobiomorphus (Teleostei: Eleotridae) amongst a morphological complex. Evolutionary Ecology Research, 11(1):109_ 123.

Stokell, G. 1962. A new species of Gobiomorphus. Transactions of the Royal Society of New Zealand. Zoology, 2(3):31-34. 
Thacker, C.E. 2009. Phylogeny of Gobioidei and placement within Acanthomorpha, with a new classification and investigation of diversification and character evolution. Copeia, 2009(1):93-104.

Thacker, C.E. 2011. Systematics of Gobiidae, p. 129136. In Patzner, R.A., Van Tassell, J.L., Kovačić, M., and Kapoor, B.G. (eds.), The Biology of Gobies. Science Publishers Inc., Enfield, NH.

Thacker, C.E. 2013. Phylogenetic placement of the European sand gobies in Gobionellidae and characterization of gobionellid lineages (Gobiiformes: Gobioidei). Zootaxa, 3619(3):369-382.

Thacker, C.E. and Roje, D.M. 2009. Phylogeny of cardinalfishes (Teleostei: Gobiiformes: Apogonidae) and the evolution of visceral bioluminescence. Molecular Phylogenetics and Evolution, 52(3):735-745.

Thacker, C.E., Satoh, T.P., Katayama, E., Harrington, R.C., Eytan, R.I., and Near, T.J. 2015. Molecular phylogeny of Percomorpha resolves Trichonotus as the sister lineage to Gobioidei (Teleostei: Gobiiformes) and confirms the polyphyly of Trachinoidei. Molecular Phylogenetics and Evolution, 93:172-179.

Théobald, N. 1934. Contribution à la paléontologie du bassin oligocène du Haut-Rhin et du territoire de Belfort - Les poissons oligocènes. Bulletin du Service de la Carte Géologique d'Alsace et de Lorraine, 2(2):117-162.

Van Tassell, J.L., Joyeux, J.-C., Macieira, R.M., and Tornabene, L. 2015. Status of Gobiosoma (Teleostei: Gobiidae) from Brazil: description of a new species, redescription of $G$. hemigymnum, molecular phylogeny of the genus, and key to Atlantic species. Zootaxa, 4007(4):451-480.

Weiler, W. 1943. Die Otolithen aus dem Jungtertiär SüdRumäniens. 1. Buglow und Sarmat. Senckenbergiana, 26(1/3):87-115.

Wienrich, G., Reinecke, T., and Schwarzhans, W. (eds) 2009. Die Fauna des marinen Miozäns von Kevelaer (Niederrhein). Band 5: Vertebraten, Elasmobranchii, Otolithen. Backhuys Publishers, Margraf Publishers, Leiden, Weikersheim.

Wiley, E.O. and Johnson, G.D. 2010. A teleost classification based on monophyletic groups, p. 123-182. In Nelson, J.S., Schultze, H.-P., and Wilson, M.V.H. (eds.), Origin and Phylogenetic Interrelationships of Teleosts. Verlag Dr. Friedrich Pfeil, München.

Winterbottom, R. 1993. Search for the gobioid sister group (Actinopterygii: Percomorpha). Bulletin of Marine Science, 52(1):395-414. 